\title{
Vertical distribution of Cletocamptus confluens (Copepoda, Harpacticoida) in relation to oxygen and sulphide microprofiles of a brackish water sulphuretum
}

\author{
K. Vopel*, J. Dehmlow, G. Arlt \\ University of Rostock, Dept. of Bíology, Marine Zoology Unit, Freiligrathstr. 7/8, D-18051 Rostock, Germany
}

\begin{abstract}
A semi-isolated brackish water sulphuretum was studied by analysing the small-scale vertical distribution of benthic metazoans in relation to oxygen, sulphide and $\mathrm{pH}$ microprofiles and their diurnal variations. Furthermore, the resistance of the harpacticoid copepod Cletocamptus confluens (Schmeil 1894) to anoxıa and sulphide was tested at different $\mathrm{pH}$ values by laboratory exposure experiments. Steep oxygen and sulphide gradients were found in the top millimetre of the mud. Experimental stagnation was accompanied by a subsurface oxygen maximum. Continuous measurements showed strong diurnal variations in the chemical environment of the mud-water interface. Apart from protozoans (not dealt with here), only 2 benthic species were farly frequent, accounting between them for $89 \%$ of all metazoans found: the harpacticoid C. confluens and the nematode Daptonema setosum (Bütschli 1874). On average, $36 \%$ of all C. confluens were found below the chemocline. Sulphide appeared to have no lethal effect in exposure experiments at $\mathrm{pH} 6.5$ and 9.5 under the conditions tested. Fleld and laboratory investigations suggest that $C$. Confluens possesses a high tolerance for short-term exposure to sulphide and anoxia. Quiescence during sulphide exposure may be important for this species, enabling it to populate unstable niches characterised by prolonged periods of anoxia and high sulphide concentrations.
\end{abstract}

KEY WORDS: Brackish water S Sulphuretum - Meiofauna Harpacticoida - Nematoda Cletocamptus confluens Daptonema setosum - Vertical distribution Sulphide

\section{INTRODUCTION}

During the summer the sheltered shallow water localities in the eulittoral zone of Hiddensee Island, Germany (southwest coast of the Baltic Sea) are characterised by regular periods of hypoxia and intense hydrogen sulphide production. Field investigations showed that these biotopes are densely populated by the mud-burrowing harpacticoid copepod Cletocamptus confluens. Unlike other harpacticoids such as Tachidius discipes Giesbrecht 1881, Nitocra spinipes Boeck 1864 and Mesochra lilljeborgi Boeck 1864, this species

\footnotetext{
·E-mail:kay.vopel@biologie.unı-rostock.de
}

is often found not only in the top but also in deeper, probably anoxic and sulphidic sediment layers.

Oxygen concentrations in the interstitial water of organically loaded sediments is mainly governed by diffusive and advective transport processes (Santschi et al. 1990). Oxygen is transported below the sediment water interface due to water pumping caused by macro-invertebrates and wave action. The depth distribution of Cletocamptus confluens, therefore, may depend on chemical microenvironments created by macrofaunal bioturbation and irrigation and is not necessarily an indication of a high tolerance of anoxia and sulphide.

In order to test whether this harpacticoid is, in fact, able to cope with anoxia and sulphide, a semi-isolated 
sulphuretum was investigated for the occurrence of metazoans in general and Cletocamptus confluens in particular. The vertical distribution of $C$. confluens was considered in connection with oxygen and sulphide microprofiles and their diurnal variations. The laboratory exposure experiments were designed to ascertain the resistance of $C$. confluens to sulphide and anoxia at different $\mathrm{pH}$ values.

\section{MATERIAL AND METHODS}

Investigation area. The studies were performed in a shallow protected oligohaline bay on the east coast of Hiddensee Island. At the edge of the bay, sulphureta developed in small pools enclosed by Phragmites and Scirpus (Suckow 1966). The pool studied $\left(400 \mathrm{~m}^{2}\right)$ was situated inside the reed belt of the island and communicated with the open water through 2 small chinnels. The changing wind direction led to frequent fluctuations in the water level of the surrounding eulittoral, so that the pool was regularly isolated. The black mud (water content: $84 \%$ wet weight, ash content: $15 \%$ dry weight, median grain size: $106 \mu \mathrm{m}$ ) was covered by thin microbial mats mainly consisting of filamentous cyanobacteria Oscillatoria sp., Lyngbya majuscula and Spirulina sp. (J Rethmeier pers comm.). Except for 1 measurement (see below), all field investigations were carried out between 12 and 24 June 1995. The salinity was $10 \%$, the water temperature ranged between 7 and $24^{\circ} \mathrm{C}$ and the water depth varied from 10 to $50 \mathrm{~cm}$.

Sample collection and analysis. Ten samples were collected for faunistic analysis. Five were taken directly from the edge of the pool by means of a small corer $\left(5 \mathrm{~cm}^{2}\right)$ and split into 10 slices with a thickness of $5 \mathrm{~mm}$ (depth 0 to $50 \mathrm{~mm}$ ), each within $1 \mathrm{~min}$. In addition, 8 mud cores were taken from the centre of the pool to measure the vertical gradients (see below) These cores were taken by means of large plastic tubes (10 cm diameter, $40 \mathrm{~cm}$ long) which could be closed at both ends. The other 5 samples were collected from the mud in the tubes following the same procedure as above. In order to avoid influencing the vertical distribution of the fauna, samples were taken $30 \mathrm{~mm}$ away from the place were the electrode penetrated into the mud. The material was treated as described in the $\mathrm{BMB}$ recommendations for meiofauna studies (Elmgren \& Radziejewska 1989). All metazoans were separated and, as far as possible, identified to species level. The vertical distribution of the dominant species was reconstructed from their abundance in the slices. The weighted mean depth $H$ (positions of the population centres) of the dominant species was calculated after normalisation of the abundance data by a square-root transformation:

$$
H=\frac{\sum_{l=1}^{10}\left(N_{1} h_{1}\right)}{\sum_{i=1}^{10}\left(N_{1}\right)}
$$

where $N$ is the number of Cletocamptus confluens or Daptonema setosum in each sediment layer, $i$, and $h(\mathrm{~mm})$ is the depth (at the midpoint) of each layer. The Wilcoxon's signed rank test was used to determine if depth distributions for $C$. confluens and $D$. setosum differed.

Measurement of oxygen, sulphide and pH. The vertical oxygen, sulphide and $\mathrm{pH}$ profiles of the first 5 mud cores were recorded within 20 min after each had been taken. After the measurement, 1 sample at a time was taken from each core for faunistic analysis. The gradients in the 3 remaining cores were recorded after simulated stagnation (without currents in the overlying water and increasing temperature) by exposing the cores to the open air for $18 \mathrm{~h}$ 106:00 to 12:00 h). In all cores the water had a depth of between 10 and $15 \mathrm{~cm}$

The variation in time of the parameters were recorded 3 times by continuous measurement at the mud-water interface: in situ (12 June 1995), in a core taken from the sampling station (2 August 1994; water temperature: 17.5 to $25^{\circ} \mathrm{C}$ ) and in 1 of the laboratory microcosms used to cultivate Cletocamptus confluens. The sensors were positioned about $1 \mathrm{~mm}$ above the mud surface in each case. A combined polarographic oxygen and ion-selective sulphide electrode (Visscher et al, 1991) and a needle combination $\mathrm{pH}$ electrode (Diamond General) were used. The combined electrode consisted of a stainless steel needle ( $1 \mathrm{~mm}$ diameter, $60^{\circ}$ angle of bevel) containing sensing tips for both oxygen (Au-plated Pt cathode, $10 \mu \mathrm{m}$ tip diameter) and sulphide (Ag wire coated with $\mathrm{Ag}_{2} \mathrm{~S}$, $100 \mu \mathrm{m}$ tip diameter) side by side and $0.5 \mathrm{~mm}$ apart. A cellulose-nitrate membrane was applied prior to the measurements. The combined sensor was polarised and activated as described by Visscher et al. (1991). Oxygen calibration ( $0 \%$ and $100 \%$ air saturation) was carried out in water overlying the mud in which the oxygen content was measured with a calibrated electrode (WTW EOT 196). For sulphide calibration a buffered system (phosphate buffer, devoid of oxygen, adjusted to $\mathrm{pH} 6.5$ or 8.5 ) was used, to which increasing amounts of a sulphide stock solution were added in increments (for further information see Van Gemerden et al. 1989). The total sulphide concentration in the stock solution was assayed by the methylene-blue method (Trüper \& Schlegel 1964). A micromanipulator, attached to a vertical stand, was used to insert the sensors into the mud incrementally or at a constant speed down to a depth of $50 \mathrm{~mm}$. The signals from the sensors were digitised by an ana- 
logue-to-digital converter, transmitted to a computer via an RS 232 serial interface and stored on a hard drive using the software 'WINDAQ' (Dataq Instruments). All sulphide concentrations are given as total sulphur concentration in the $\mathrm{pH}$-dependent equilibrium $\mathrm{H}_{2} \mathrm{~S} \leftrightarrow \mathrm{HS}^{-}+\mathrm{H}^{+} \leftrightarrow \mathrm{S}^{2-}+2 \mathrm{H}^{+}$.

Cultivation and sulphide exposure. Cletocamptus confluens specimens were exposed to anoxia and sulphide in a flow-through system $\left(0.06 \mathrm{ml} \mathrm{min}^{-1}\right)$ using glass Pasteur pipettes as incubation vessels. In order to keep the $C$. confluens in the vessels a mesh was placed on the outlets of the pipettes. No sediment was added. The adult female $C$. confluens specimens used were taken from laboratory cultures in artificially illuminated $\left(6 \mathrm{~h}\right.$ dark at $18^{\circ} \mathrm{C}, 18 \mathrm{~h}$ light at $20^{\circ} \mathrm{C}, 10 \%$ ) microcosms. All microcosms had been established in glass cylinders (diameter: $6 \mathrm{~cm}$, length: $23 \mathrm{~cm}$ ) filled with $1 / 3$ mud and $2 / 3$ water. The $C$. confluens were exposed in darkness and under starvation using filtered brackish water $\left(0.2 \mu \mathrm{m}, 10 \%, 20^{\circ} \mathrm{C}\right)$ with the $\mathrm{pH}$ adjusted to 6.5 and 9.5 by means of HEPES buffer (50 mmol $\mathrm{I}^{-1}$ ). The sulphide concentration (1.9 to $2.7 \mathrm{mmol}^{-1}$ ) was adjusted by adding sodium sulphide crystals after gasification of the water with nitrogen. Both the sulphide concentration and the $\mathrm{pH}$ were measured at the beginning, during and at the end of each exposure. The $\mathrm{pH}$ increased by 0.3 at most after addition of sodium sulphide to the anoxic water. During the experiments, the sulphide concentration decreased by a maximum of $0.5 \mathrm{mmol} \mathrm{l}^{-1}$ (96 h exposure). C. conflu- ens held under anoxic conditions served as controls. The harpacticoids were adapted by transferring them into filtered water with the experimental $\mathrm{pH} 24 \mathrm{~h}$ before the exposure experiments. Additionally, the hatching success of nauplii was tested after exposure of ovigerous females to 1.0 and $1.5 \mathrm{mmol}^{-1}$ sulphide at $\mathrm{pH}$ 7.5. In these experiments, 3 groups of $10 \mathrm{C}$. confluens were each incubated for 2, 4 and $8 \mathrm{~h}$ in stoppered flasks.

\section{RESULTS}

\section{Overall colonisation}

Analysis of the samples taken from the edge of the pool $(n=5)$ revealed a mean metazoan abundance of $158 \pm 97$ ind $\left(10 \mathrm{~cm}^{2}\right)^{-1}$. The overall colonisation of the central area was about $452 \pm 106$ ind. $\left(10 \mathrm{~cm}^{2}\right)^{-1}$. Apart from protozoans (not dealt with here), only 2 meiobenthic species were fairly frequent and accounted between them for 89 and $88 \%$ of all metazoans at the 2 sampling locations: the nematode Daptonema setosum (Bütschli 1874) and the harpacticoid Cletocamptus confluens (Table 1, Fig. 1). No macrobenthic invertebrates were found. The relative abundance of $C$. confluens was about $46 \%$ at the edge and $30 \%$ in the central area. The mean abundance of $D$. setosum was 4 times higher in the central area than in the mud at the edge of the pool. The nematodes Daptonema

Table 1. Abundances and relative abundances ( \pm confidence limits, $\alpha=0.05$ ) of benthic metazoans found in the central area and at the edges of the sulphuretum $\left(0\right.$ to $5 \mathrm{~cm}$ depth, June 1995). Sparse: less than 5 ind. $\left(10 \mathrm{~cm}^{2}\right)^{-1}$

\begin{tabular}{|c|c|c|c|c|}
\hline & \multicolumn{2}{|c|}{ Central area $(n=5)$} & \multicolumn{2}{|c|}{ Edge area $(n=5)$} \\
\hline & $\begin{array}{l}\text { Abundance } \\
\text { [ind. }\left(10 \mathrm{~cm}^{2}\right)^{-1} \text { ] }\end{array}$ & $\begin{array}{l}\text { Relative abundance } \\
\qquad(\%)\end{array}$ & $\begin{array}{l}\text { Abundance } \\
{\left[\text { ind. }\left(10 \mathrm{~cm}^{2}\right)^{-1}\right]}\end{array}$ & $\begin{array}{l}\text { Relative abundance } \\
\qquad(\%)\end{array}$ \\
\hline Protohydra leuckarti Greef 1868 & $\cdot$ & & - & \\
\hline Turbellaria & - & & $\cdot$ & \\
\hline Sabatieria pulchra (Schneider 1906) & $10 \pm 11$ & $2 \pm 2$ & $\cdot$ & \\
\hline Daptonema setosum (Bütschli 1874) & $279 \pm 119$ & $58 \pm 16$ & $69 \pm 51$ & $43 \pm 11$ \\
\hline Daptonema trabeculosum (Schneider 1906) & $17 \pm 10$ & $4 \pm 3$ & $\cdot$ & \\
\hline Anoplostoma viviparum Bütschli 1874 & $\cdot$ & & $\cdot$ & \\
\hline Chromadorita tenuis (Schneider 1906) & $\cdot$ & & $\cdot$ & \\
\hline Dichromadora sp. & $\cdot$ & & - & \\
\hline Desmolaimus sp. & - & & • & \\
\hline Axonolaimus sp. & - & & • & \\
\hline Diplolaimella ocellata (Bütschli 1874) & $\cdot$ & & $\cdot$ & \\
\hline Leptolaimus sp. & $\cdot$ & & - & \\
\hline Nais elinguis O. F. Müller 1774 & $\cdot$ & & - & \\
\hline Paranais litoralis (O. F. Müller 1788) & $\cdot$ & & - & \\
\hline Amphichaeta sannio Kallstenius 1892 & $\cdot$ & & - & \\
\hline $\begin{array}{l}\text { Cletocamptus confluens (Schmeil 1894) } \\
\text { Cyprideis torosa (Jones 1850) }\end{array}$ & $123 \pm 37$ & $30 \pm 14$ & $72 \pm 42$ & $46 \pm 5$ \\
\hline Total fauna & $452 \pm 106$ & & $158 \pm 97$ & \\
\hline
\end{tabular}




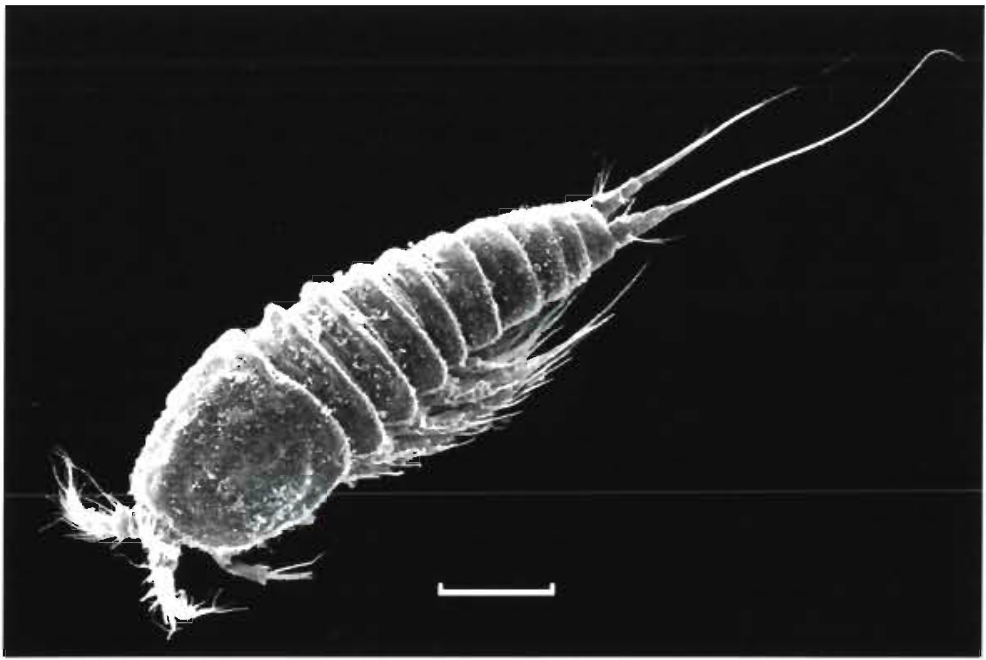

Fig. 1. Female Cletocamptus confluens (Schmeil 1894). Scale bar $=100 \mu \mathrm{m}$

\section{Vertical gradients of oxygen, sulphide and $\mathbf{p H}$}

The mud of 5 cores taken from the central area of the pool contained oxygen down to a depth of 2 to $3 \mathrm{~mm}$. Below this, the sulphide concentration increased, reaching its highest value of 3 to $4.5 \mathrm{mmol}$ $\mathrm{I}^{-1}$ in the bottom layers (Fig. 2). A stagnation period was simulated by exposing 3 cores filled with mud and overlying water for $18 \mathrm{~h}$ to the open air. Thereafter, oxygen maxima were found 1 to $2 \mathrm{~mm}$ below the mud surface. The position of the chemocline was somewhat deeper at 3 to $4 \mathrm{~mm}$. In Fig. 3 an example of a typical gradient was plotted from 1 measurement. trabeculosum (Schneider 1906) and Sabatieria pulchra (Schneider 1906) were far less common. Another 7 nematode species, the hydropolyp Protohydra leuckarti Greef 1868, turbellarians, the oligochaetes Nais elinguis O. F. Müller 1774, Paranais litoralis (O. F. Müller 1788), Amphichaeta sannio Kallstenius 1892 and the ostracod Cyprideis torosa (Jones 1850), which otherwise is quite common in the eulittoral of the island, were found only sporadically lless than 5 ind. $\left(10 \mathrm{~cm}^{2}\right)^{-1}$, Table 1]

\section{Vertical distribution of Cletocamptus confluens and Daptonema setosum}

Altogether 489 specimens of Cletocamptus confluens and 870 specimens of Daptonema setosum were found. They occurred at depths down to $20 \mathrm{~mm}$ and $35 \mathrm{~mm}$, respectively. About $36 \%$ of all $C$. confluens and $56 \%$ of all $D$. setosum were found deeper than $5 \mathrm{~mm}$. To compare the vertical distributions of these species in the mud at the edge and in the centre of the pool, the position of each population centre was calculated (weighted mean depth \pm SD). For $C$. confluens the weighted mean depth was $4.6 \pm 1.1 \mathrm{~mm}$ at the edge and $5.5 \pm 0.8 \mathrm{~mm}$ in the central area. The corresponding values for $D$. setosum were $6.5 \pm$ $1.0 \mathrm{~mm}$ and $7.7 \pm 1.4 \mathrm{~mm}$. There were no significant differences between the values for both sampling stations. The Wilcoxon's signed rank test for all samples $(\mathrm{n}=10)$ showed significant differences (at the $p<0.01$ level) in depth distribution of $D$. setosum and $C$. confluens loverall weighted mean depth was $7.1 \pm 1.4 \mathrm{~mm}$ for $D$. setosum and $5.0 \pm 1.1 \mathrm{~mm}$ for C. confluens)

\section{Temporal variability of mud surface oxygen, sulphide and $\mathrm{pH}$}

The 3 continuous measurements indicated strong variations in the chemical environment at the mudwater interface. Both in situ and core recordings showed rapidly declining $\mathrm{pH}$ values and oxygen concentrations even before sunset (Fig. 4). During the night the mud surface had a whitish colour due to sulphur bacteria (Beggiatoa). No free oxygen could be detected during this phase, and sulphide concentrations increased. The surface remained anoxic for some time after sunrise. Whereas the in situ measurement was interrupted after $11 \mathrm{~h}$ (Fig, 4a), the $18 \mathrm{~h}$ record in the corer showed the return of oxygen after direct sunlight illumination. In this case the oxygen concentration increased to about $700 \mu \mathrm{mol} \mathrm{l}^{-1}$ and then dropped to between 300 and $400 \mathrm{umol} \mathrm{l}^{-1}$ (Fig. 4b)

As in the field, the mud surface in the vessels used for culturing harpacticoids was covered by a thin cyanobacterial film. The measurements indicated that these microcosms were also characterised by extreme changes in the course of the light/dark cycle: the $\mathrm{pH}$ value decreased and the sulphide concentration rose drastically during darkness (Fig 5). Cultures of Cletocamptus confluens developed successfully in the laboratory even under these conditions and provided material for the exposure experiments

\section{Exposure of Cletocamptus confluens to sulphide and anoxia}

The survival rate of female Cletocamptus confluens did not drop below $96 \%$ in any case during exposure to sulphide and anoxia at pH 6.5 and 9.5 (Table 2). C. 


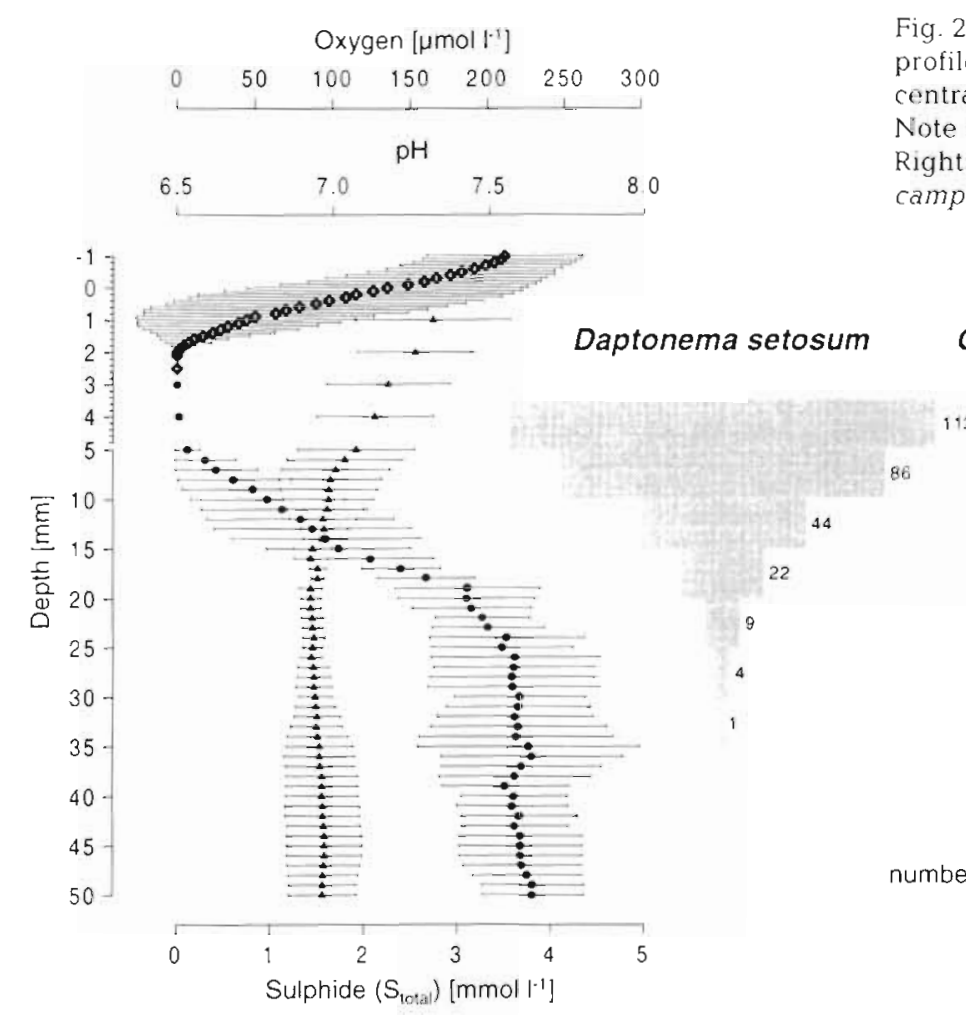

Fig. 2. Left: Vertical $(\diamond)$ oxygen, $(\bullet)$ sulphide $\left(S_{\text {total }}\right)$ and $(\mathbf{\Delta}) \mathrm{pH}$ profile plotted from measurements in 5 cores taken from the central area of the sulphuretum (mean values $\pm S D, n=5$ ) Note the varying scales from -1 to 5 and 5 to $50 \mathrm{~mm}$ depth. Right: Vertical distrabution of the harpacticoid copepod Cletocamptus confluens and the nematode Daptonema setosum in the mud of these 5 cores (mean values, $n=5$ )

Cletocamptus confluens

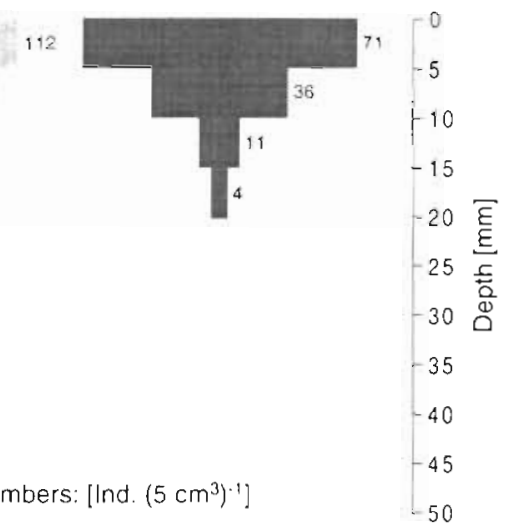

confluens exposed to sulphide and anoxia remained quiescent during the tests, but became active again after a few minutes in normoxic water. Those exposed only to anoxia were active immediately after being transferred to normoxic water or even kept on moving during the tests. Hatching of the nauplii from altogether 60 ovigerous females was not affected by 2,4 or $8 \mathrm{~h}$ exposures to 1.0 or $1.5 \mathrm{mmol}^{-1}$ sulphide $(\mathrm{pH} \mathrm{7.5)}$. After exposure, nauplii hatched from at least $90 \%$ of all egg sacs tested.

\section{DISCUSSION}

\section{Spatial heterogeneity}

The shallow water mud in the eulittoral zone of Hiddensee Island is densely populated by the polychaete Nereis diversicolor O. F. Müller 1776 and the amphipod Corophium volutator (Pallas 1766). The water flow through the burrows made and ventilated by the inhabitants and sediment mixing caused by their movements give rise to a spatial heterogeneity and temporal variability of the benthic chemical environment. Due to intermittent irrigation, oxygenated water is pumped into the deeper mud layers (K. Vopel unpubl.) creating microenvironments with a variable oxygen flux and concentration adja-

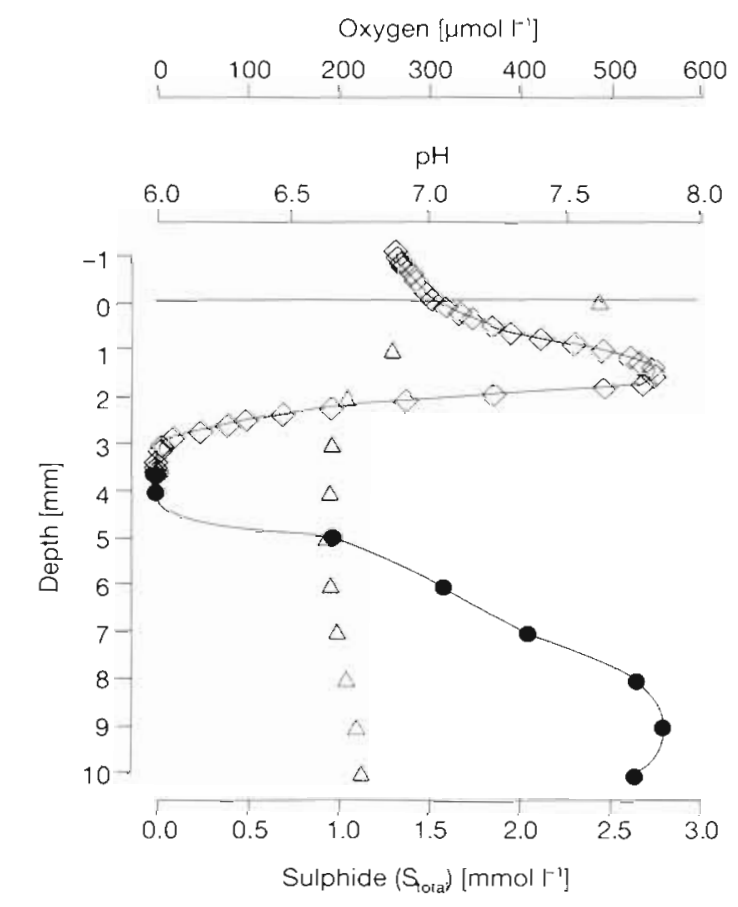

Fig. 3. Typical $(\diamond)$ oxygen, $(\bullet)$ sulphide $\left(S_{\text {totat }}\right)$ and $(\Delta) \mathrm{pH}$ profile in a mud core taken from the sulphuretum (June 1995). Prior to measurement the core was stored for $18 \mathrm{~h}$ under natural light conditions (simulated stagnation). The temperature of the overlying water was $20^{\circ} \mathrm{C}$. Oxygenic photosynthesis caused supersaturation in the topmost layer The sediment surface is indicated by a bar at a depth of $0 \mathrm{~mm}$ 

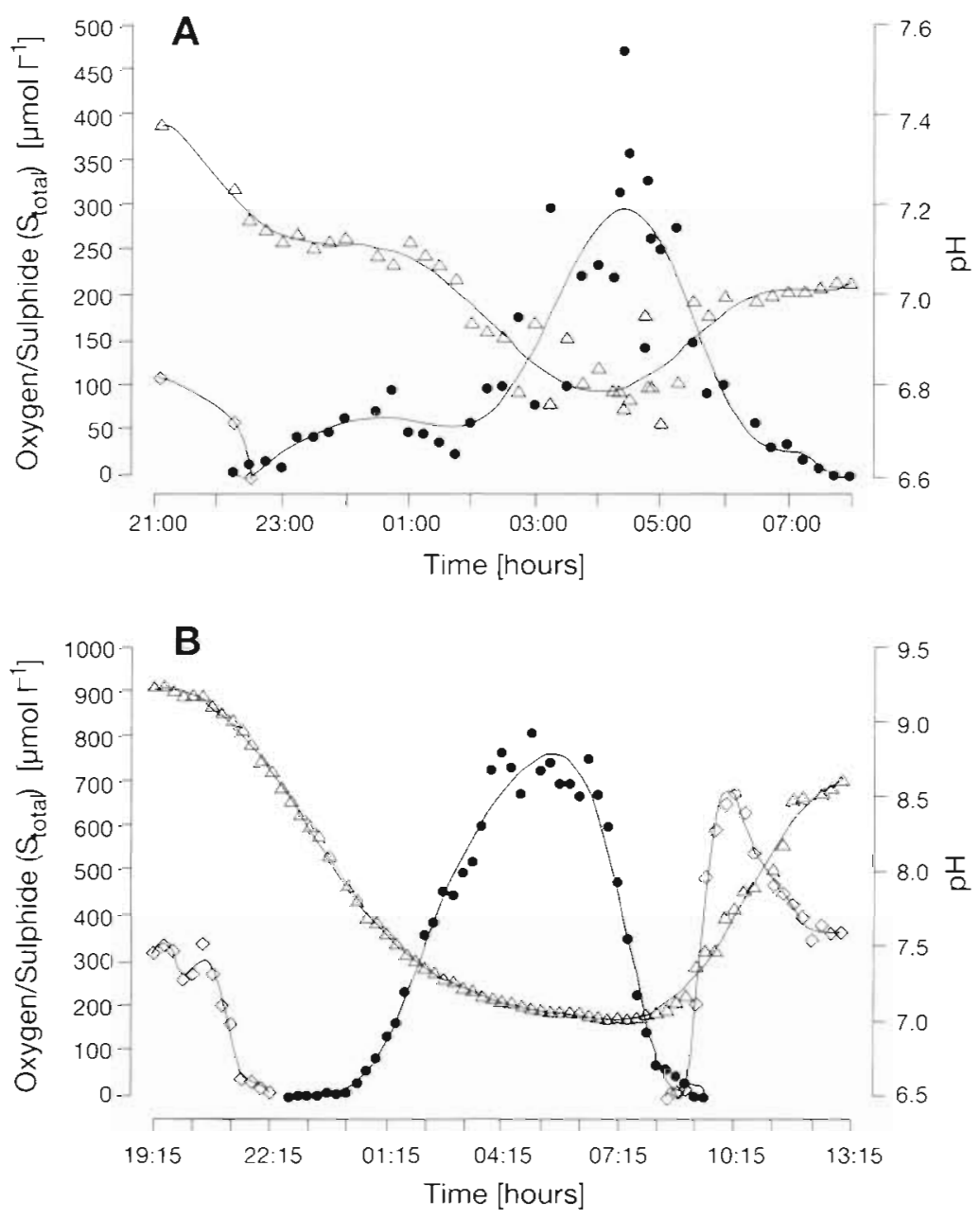

Fig. 4. Diurnal variability of $(\diamond)$ oxygen, $(\bullet)$ sulphide $\left(S_{\text {total }}\right)$ and $(\Delta) \mathrm{pH}$ at the mud-water interface. (A) An in situ measurement 12 June 1995; sunset: $21: 30 \mathrm{~h}$, sunrise: $05: 10 \mathrm{~h}_{\text {; }}$ overcast; water temperature: 14 to $18^{\circ} \mathrm{C}$. (B) $\mathrm{A}$ measurement performed in a stagnant core sample taken from the sulphuretum 2 August 1994; sunset: 22:30 h, sunrise: $04: 15$ hi cloudless; water temperature: 17.5 to $25^{\circ} \mathrm{C}$

Table 2. Survival rate of female Cletocamptus confluens after exposure to anoxia and sulphide/anoxia at 2 different $\mathrm{pH}$ values (mean values, $\mathrm{n}=8$ ). C. confluens were kept in darkness under starvation conditions in a flow-through incubator set to a temperature of $20^{\circ} \mathrm{C}$ and a salinity of $10 \%$ ( 40 specimens in each replicate)

\begin{tabular}{|ccccc|}
\hline pH & $\begin{array}{c}\text { Sulphide } \\
\left(\text { mmol }^{-1}\right)\end{array}$ & $\begin{array}{c}\text { Exposure } \\
\text { time (h) }\end{array}$ & \multicolumn{2}{c|}{ Survival rate (\%) } \\
\hline & & 24 & SD \\
9.5 & 2.7 & 24 & 99.4 & 1.1 \\
9.5 & - & 96 & 99.4 & 1.2 \\
9.5 & 2.0 & 96 & 95.9 & 2.3 \\
9.5 & - & 24 & 99.2 & 1.3 \\
6.5 & 1.9 & 24 & 98.4 & 2.4 \\
6.5 & - & 96 & 99.7 & 0.9 \\
6.5 & 2.1 & 96 & 96.9 & 2.9 \\
6.5 & - & & 96.8 & 2.3 \\
& & & & \\
\hline
\end{tabular}

cent to macrofaunal burrows (Forster 1996). Consequently, the vertical distribution of meiofauna determined by taking and subdividing mud cores is rather unsuitable for obtaining information about possible preferences of the species for oxic or sulphidic sediments as they live in an environment that fluctuates in 3 dimensions. However, this does not apply to the mud of the semiisolated pool we studied. During sampling no macroscopic or even microscopic burrows were found. Owing to the lack of macro-infauna and currents in the overlying water, the depth distribution of oxygen in the sulphuretum is probably governed mainly by the photosynthesis of filamentous cyanobacteria and the diffusion of oxygen and sulphide. Therefore, the distribution of both parameters were relatively homogeneous in space, but not in time. In other words, in this case it was possible to relate profiles measured at discrete points to the vertical distribution of the fauna in the adjoining areas (Fig. 2). Nevertheless, the small-scale vertical distribution of the fauna just above and below the chemocline is difficult to study due to the steep gradients and the high water content of the mud. The latter makes it hard to split the samples into sections smaller than a couple of millimetres.

\section{Overall colonisation}

The term 'sulphuretum' describes biotopes in which the sulphur cycle predominates (Baas Becking 1925). Such light-exposed anaerobic systems are common in the eulittoral zone off Hiddensee Island. They are characterised by strong sulphide development caused by anaerobic decomposition of organic material such as accumulated drift-weed. Fenchel (1969) studied sulphureta on the shore of Nivå Bay, Denmark and found a remarkably diverse microfauna, numerous harpacticoids, nematodes, ostracodes and a few representatives of the macrofauna. Comparably dense populations of animals were found by Vopel \& Arlt (1995) in floating cyanobacterial mats. However, the sulphu- 


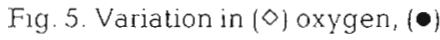
sulphide $(S .$.$) and (\Delta) \mathrm{pH}$ at the mud-water interface in a culture vessel. The data were plotted from a measurement during a light/ dark shift. The culture vessel was kept in a refrigerated incubator set to give $18 \mathrm{~h}$ light at $20^{\circ} \mathrm{C}, 6 \mathrm{~h}$ dark at $18^{\circ} \mathrm{C}$

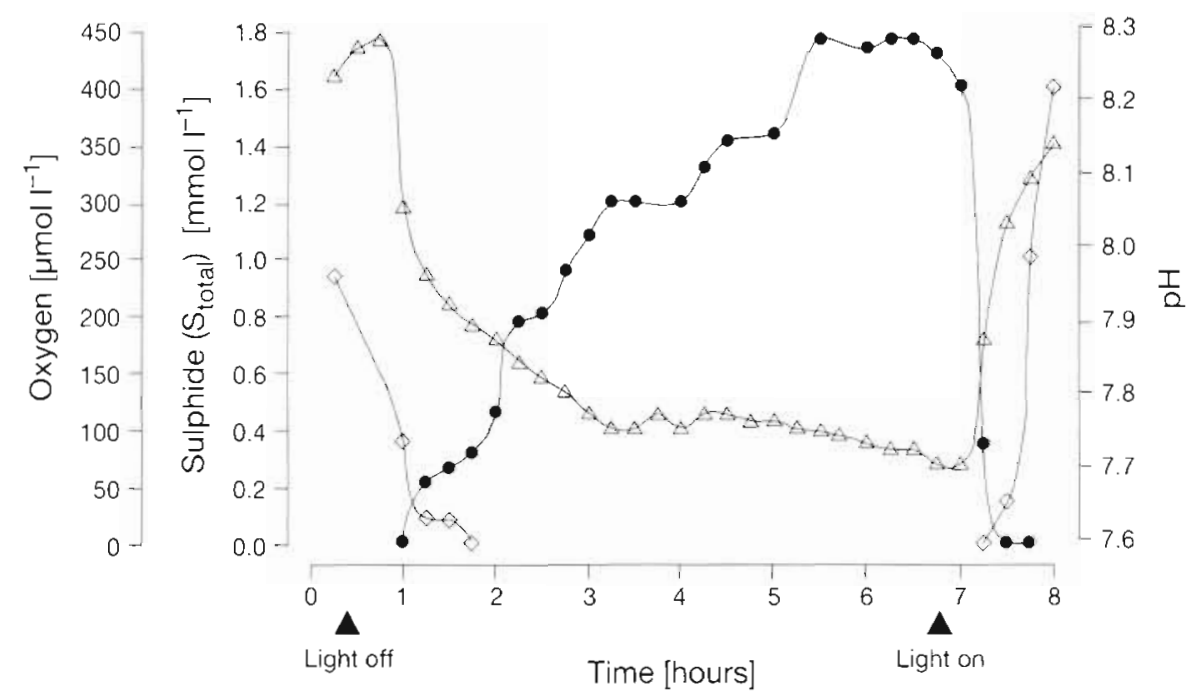

\section{Vertical distribution of Cletocamptus confluens and Daptonema setosum}

retum we studied contained only a small number of metazoan species. In the sediment adjacent to the pool, the nematode species Daptonema setosum, Sabatieria pulchra, Anoplostoma viviparum and Daptonema trabeculosum are always quite abundant, of which $D$. trabeculosum and $S$. pulchra predominated in deeper sediment layers (Vopel \& Arlt 1995) According to Jensen (1984), the latter obviously prefers anoxic or hypoxic conditions. However, both species were less common in the pool. Only D. setosum and, unexpectedly, the harpacticoid $C$. confluens could be considered dominant, accounting between them for $89 \%$ of all metazoans found. They were also frequent in floating cyanobacterial mats rising up from the sediment of the adjacent area. D. setosum inhabits not only the mud pool and floating cyanobacterial mats, but also sediments of different qualities, whereas $C$. confluens seems to be restricted to organically loaded, more or less isolated biotops. The species was found in brackish water off the island as early as 1933 (Schäfer 1936). Cattle had left depressions containing turbid water in an almost dried out beach pool. Nevertheless, the mud of the pools, which smelt strongly of hydrogen sulphide, was densely populated. Lassérre et al. (1975) studied periodically isolated lagoons subject to seasonal anoxic conditions in the sediment and fluctuating salinities. They found that $C$. confluens was dominant among the harpacticoids with relative abundances of 40 to $98 \%$. Castell (1992) also reported that this species predominates in isolated locations.

The metazoans inhabiting the sulphuretum must not only cope with anoxia and sulphide, but also with high temperatures and occasional dryness caused by changes in water level. This might explain the lower metazoan abundance in the sulphuretum, especially at the more exposed edges (Table 1).
There seemed to be no differences between samples taken from the sulphuretum itself and those taken from cores in which the gradients of sediment parameters had been recorded regarding the mean depth distributions of Cletocamptus confluens and Daptonema setosum. Thus, it is unlikely that the handling of the cores influenced the vertical distribution of the fauna. Since the chemocline was only 2 to $4 \mathrm{~mm}$ below the mud surface, animals in the second fraction $(5$ to $10 \mathrm{~mm}$ ) of each core were already in the reducing zone (Fig. 2). However, despite the fast and accurate sampling procedure, effects on the vertical distribution through flight reaction during the subdivision procedure cannot be completely excluded. According to our laboratory observations, $C$. confluens is a holobenthic infaunal burrower which does not build tiny tubes as described for Stenhelia palustris Brady 1868 and Pseudostenhelia wellsi Coull \& Fleeger 1977 (Lorenzen 1969. Chandler \& Fleeger 1984, Nehring 1993). Such structures would modify local oxygen and sulphide flux rates and possibly allow the harpacticoid to inhabit sulphidic mud layers.

Only a few movements are needed to take Cletocamptus confluens from the oxic into the sulphidic layers. It is unlikely that this species either is restricted to oxidised mud or continuously exposed to sulphide. As the in situ measurement indicate, the water layers close to the bottom become anoxic and sulphidic at night owing to the interruption of light-driven oxygen production and sulphide oxidation (Fig. 4A). Regardless of possible sampling effects on distribution, C. confluens are regularly exposed to anoxia and sulphide not only by burrowing but also by the shift of the 
chemocline at night. Consequently, even if $C$. confluens lives predominantly in the surface layer or responds to unfavourable conditions by migration, the harpacticoid must still cope with sulphide and anoxia, at least for a limited time.

\section{Stagnation periods}

In summer, periodic stagnation, absence of water currents and high water temperatures are characteristic of the semi-isolated pools in the reed belt of the island. The measurements performed after simulated stagnation (Fig. 3) indicate that the top few millimetres of the mud were still oxic by day. The oxygen produced photosynthetically by cyanobacteria (and diatoms) supersaturates the interstitial water below the mud surface. Consequently, extreme oxygen and sulphide concentrations can be found in close proximity to each other. Some of the oxygen produced by photosynthesis in the benthic cyanobacterial film is stored as bubbles enclosed in mucus. The production of such bubbles has often been observed in the biotope we studied, where they may serve as natural oxygen reservoirs during light/dark cycles (Jørgensen et al. 1983). Moreover, the filamentous cyanobacteria at the location are able to oxidise sulphide at a high rate under anaerobic conditions (J. Rethmeier pers. comm.). Both phenomena can delay and reduce the rate of diurnal change in abiotic conditions at the mud-water interface. But despite the intense oxygen production during the day, sulphide diffuses into the overlying water, especially during calm nights, turning the condition of the mud surface to anoxic for several hours (Fig. 4B). When insolation becomes sufficiently intense again after daybreak, the oxygen produced photosynthetically by the cyanobacteria oxidises the sulphide.

\section{Sulphide resistance of Cletocamptus confluens}

The burrowing of Cletocamptus confluens in the anaerobic system of the sulphuretum and the diurnal variations in the chemical environment of the mudwater interface require tolerance to anoxia and sulphide for at least a limited time. As shown in Figs. $2 \& 3$, $\mathrm{pH}$ values in the field ranged from around 6.5 to 9.0 . Since the concentration of $\left[\mathrm{H}_{2} \mathrm{~S}\right]$, [HS ] and $\left[\mathrm{S}^{2-}{ }_{n}\right]$ in aqueous solutions is a function of $\mathrm{pH}$ (Millero 1986), $C$. confluens have to cope with varying concentrations of each sulphide species as total sulphide concentration and $\mathrm{pH}$ values change. In the case of the experimental $\mathrm{pH}$ values, the portion of $\mathrm{H}_{2} \mathrm{~S}$ primarily entering the internal tissues of the animals by diffusion (Powell 1989) was less than $0.01 \%$ at $\mathrm{pH} 9.5$ and almost $80 \%$ of the total reduced sulphur at $\mathrm{pH} 6.5$ Consequently, the concentration of $\mathrm{H}_{2} \mathrm{~S}$ was approximately 10000 times higher at $\mathrm{pH} 6.5$ than at $\mathrm{pH} 9.5$ Therefore, sulphide should become increasingly toxic with decreasing $\mathrm{pH}$. Due to the size of the harpacticoids there is no need for respiratory and circulatory organs. Although nothing is known about the diffusion of the several sulphide species through the exoskeleton of $C$. confluens and their concentration in the tissue, it can be assumed that diffusion across the body surface is sufficient not only to provide $C$. confluens with oxygen, but also allowing $\mathrm{H}_{2} \mathrm{~S}$ to enter. Nevertheless, no lethal effects were observed under the test conditions at pH 6.5 and $\mathrm{pH} 9.5$ during the exposure experiments. Confirming our field findings, this indicates that for $C$. confluens anoxia and sulphide may not be as much of a problem as generally assumed for benthic copepods. These results are in contrast to earlier studies which regarded copepods as particulariy sensitive to hypoxic conditions and considered them as the classical example of 'oxibiotic meiofauna' (Lasserre \& Renaud-Mornant 1973, Vernberg \& Coull 1975, Powell 1989, Coull \& Chandler 1992).

Earlier SEM examinations of Cletocamptus confluens showed that specimens from the pool were covered with dense lawns of cyanobacteria which give them a green appearance (Vopel \& Arlt 1995). Such lawns were found only sporadically on the harpacticoids grown in laboratory cultures. However, due to the cuticular setae, some bacteria are always attached to the animal surface. The harpacticoids tested in the flow-through incubator were not free of bacteria, but in view of the small size of the $C$. confluens and the high experimental sulphide concentrations and the permanent flow, it seems unlikely that the diffusion of sulphide from the exposure medium to the tissue of C. confluens was impeded by epibiontic bacteria.

The specimens exposed to sulphide remained quiescent during the tests. Obviously the experimental conditions induced a 'hypo-metabolic state' followed by resumption of the normal state as soon as favourable conditions were restored (Brendonck 1996). Such a short-term and irregular response may function as a buffer system within the life cycle, enabling the species to bridge periods of environmental deterioration (Dahms 1995). Although it seems unlikely that Cletocamptus confluens is able to survive exclusively and actively in highly sulphidic mud layers, the ability to adopt a quiescent state may be important for occupying unstable niches which are subject to high sulphide concentrations and fluctuating water levels (dry out or freeze) It has been shown for Cletocamptus retrogressus Schmankevitch 1875 that females survive summer drying in brackish marshes (Champeau \& Francezon 1991). After reactivation, females that had 
been inseminated before drying laid several successive egg sacs. The eggs were fertilised by spermatozoa that remained alive in the genital tract of the inactive female throughout the period of dryness. Although it is not known whether this applies to $C$. confluens, we suppose that a similar reproductive cycle allows the population to grow again after prolonged stagnation periods with anoxia and high sulphide concentrations.

Since only female specimens were exposed, although other factors such as food supply, salinity and temperature are doubtless also important, the reason for the ecological success of Cletocamptus confluens remains unknown. More information is needed to understand the interplay of physiological, morphological and behavioural adaptations to anoxia and sulphide and their influence on life history events and reproductive phases.

Acknowledgements. We are grateful to the anonymous reviewers who gave us many helpful suggestions. Mr Bahlo of the Institut für Ostseeforschung Warnemünde assisted us in making the SEM micrograph (Cam Scan 44 Analytic WEX). The work was supported by the Bundesministerium fur Bildung, Wissenschaft und Technologie (BMBF) under the project DYSMON II (03F0028A0).

\section{LITERATURE CITED}

Baas Becking LGM (1925) Studies on the sulphur bacteria. Ann Bot 39:613-650

Brendonck L (1996) Diapause, quiescence, hatching requirements: what we can learn from large freshwater branchıpods (Crustacea: Branchiopoda: Anostraca, Notostraca, Conchostracal. Hydrobiologia 320:85-97

Castel J (1992) The meiofauna of coastal lagoon ecosystems and their importance in the food web. Vie Milieu 42: $125-135$

Champeau A, Francezon P (1991) Laying and fecundity of females of the harpacticoid copepod Cletocamptus retrogressus, Schmankevitch, after their survival and drying. Cr Acad Sci, Paris, t 8, Sér III 312:389-393

Chandler GT, Fleeger JW (1984) Tube-building by a marine meiobenthic harpacticoid copepod. Mar Biol 82:15-19

Coull BC, Chandler GT (1992) Pollution and meiofauna: field, laboratory, and mesocosm studies. Oceanogr Mar Biol Annu Rev 30:191-271

Dahms HU (1995) Dormancy in the Copepoda - an overview. Hydrobiologia 306:199-211

Elmgren R, Radziejewska T (1989) Recommendations for quantitative benthic meiofauna studies in the Baltic. BMB Publication 12:1-20

Fenche! T (1969) The ecology of marine microbenthos IV Structure and function of the benthic ecosystem, its chemical and physical factors and the microfauna communities

This article was submitted to the editor with special reference to the ciliated protozoa. Ophelıa $6: 1-182$

Forster S (1996) Spatial and temporal distribution of oxidation events occurring below the sediment-water interface. PSZN I: Mar Ecol 17:309-319

Jorgensen BB, Revsbech NP, Cohen Y (1983) Photosynthesis and structure of benthic microbial mats: microelectrode and SEM studies of four cyanobacterial communities. Limnol Oceanogr 28:1075-1093

Jensen P (1984) Ecology of benthic and epiphytic nematodes in brackish waters. Hydrobiologia 108:201-217

Lasserre P, Renaud-Mornant J (1973) Resistance and respiratory physiology of intertidal meiofauna to oxygendeficiency. Neth J Sea Res 7:290-302

Lasserre P. Renaud-Mornant J, Castel J (1975) Metabolic actuvities of meiofaunal communities in a semi-enclosed lagoon. Possibilities of trophic competition between meiofauna and mugilid fish. Tenth Eur Symp Mar Biol 2: $393-414$

Lorenzen S (1969) Harpacticoiden aus dem lenitischen Watt und den Salzwiesen der Nordseeküste. Kiel Meeresforsch $25: 215-223$

Millero FJ (1986) The thermodynamics and kinetics of the hydrogen sulfide system in natural waters. Mar Chem 18:121-147

Nehring $S$ (1993) Tube-dwelling meiofauna in marine sediments. Int Rev ges Hydrobiol 78:521-534

Powell E (1989) Oxygen, sulfide and diffusion: why thiobiotic meiofauna must be sulfide-insensitive first-order respirers. J Mar Res 47:887-932

Santschi P, Höhener P, Benoit G, Buchholtz-ten Brink M (1990) Chemical processes at the sediment-water interface. Mar Chem 30:269-315

Schäfer HW (1936) Harpacticoiden aus dem Brackwasser der Insel Hiddensee. Zool Jahrb Abt Syst Okol Geogr Tiere $68: 44 j-588$

Suckow R (1966) Schwefelmikrobengesollschaften der Seeund Boddengewässer von Hiddensee. Z Allg Mikrobiol 6 : 309-315

Trüper HG, Schlegel HG (1964) Sulpher metabolism in Thiorhodaceac 1 Qualitative measurements in growing cultures of Chromatium okeni. Ant Leeuwenhoek 30 : $225-238$

Van Gemerden H, Tughan CS, De Wit R, Herbert RA (1989) Lamınated microbial ecosystems on sheltered beaches in Scapa Flow, Orkney Island. FEMS Microbiol Ecol 62: $87-102$

Vernberg WB, Coull BC (1975) Multiple factor effects of environmental parameters on the physiology, ecology, and distribution of some marine meiofauna. Cah Biol Mar 16: $721-732$

Visscher PT, Beukema J, Van Gemerden H (1991) In situ characterization of sediments: measurements of oxygen and sulfide profiles with a novel combined needle electrode. Limnol Ocranogr 36:1476-1480

Vopel K. Arlt G (1995) The fauna of floating cyanobacterial mats in the oligohaline eulittoral zone off Hiddensee (south-west coast of the Baltic Sea). PSZN I: Mar Ecol $16: 217-231$

Manuscript first recelved: February 9, 1996

Revised version accepted: July 3, 1996 